\title{
Anthropometric, functional capacity, and oxidative stress changes in Brazilian community-living elderly subjects. A longitudinal study ts
}

\author{
Priscila Lucelia Moreira ${ }^{\mathrm{a}, *}$, Camila Renata Correa ${ }^{\mathrm{b}}$, José Eduardo Correntec, \\ Luis Cuadrado Martin ${ }^{\mathrm{a}}$, Paulo Jose Fortes Villas Boas ${ }^{\mathrm{a}}$, Ana Lucia Anjos Ferreira ${ }^{\mathrm{a}}$ \\ a Department of Internal Medicine, Botucatu Medical School, Sao Paulo State University (UNESP), Botucatu, SP, Brazil \\ ${ }^{\mathrm{b}}$ Post-Graduation Program in Pathology, Botucatu Medical School at São Paulo State University (UNESP), Botucatu, SP, Brazil \\ ${ }^{\mathrm{c}}$ Department of Biostatistics, Botucatu, Institute of Biosciences at Sao Paulo State University (UNESP), Botucatu, SP, Brazil
}

\section{A R T I C L E I N F O}

\section{Article history:}

Received 23 July 2015

Received in revised form 10 May 2016

Accepted 29 May 2016

Available online 6 June 2016

\section{Keywords:}

Anthropometry

Oxidative stress

Disability

Hypertension

Arthritis

Brazilian elderly

\begin{abstract}
A B S T R A C T
Objective: To examine the changes and relationships among anthropometric, functional and plasma oxidative stress markers in elderly.

Design: longitudinal study.

Setting: measurements in 2008 and 2010.

Participants: 103 community-dwelling men and women aged 67-92.

Measurements: Anthropometric parameters [waist, hip, arm and calf circumferences; waist-hip ratio, triceps skinfold thickness and others], basic (ADL) and instrumental activities of daily living (IADL)] and plasma oxidative stress markers ( $\alpha$-tocopherol, $\beta$-carotene and malondialdehyde) were assessed in 2008 and 2010.

Results: ADL, IADL, body weight, skinfold thickness and circumferences of calf and arm decreased and waist and waist-hip ratio increased from 2008 to 2010. $\alpha$-Tocopherol decreased and malondialdehyde plasma levels increased during the study period. In multiple logistic regression analyses, increased age $(\mathrm{OR}=1.12$; IC: $1.02-1.23 ; \mathrm{p}=0.02$ ), female gender ( $\mathrm{OR}=8.43$; IC: $1.23-57.58 ; \mathrm{p}=0.03$ ), hypertension $(\mathrm{OR}=0.22$; IC: $0.06-0.79 ; \mathrm{p}=0.02)$, arthritis/arthrosis (OR=0.09; IC: $0.009-0.87 ; \mathrm{p}=0.04)$ and depression $(\mathrm{OR}=0.20$; IC: $0.04-1.03 ; \mathrm{p}=0.05)$ were independent risk factors for functional decline.

Conclusion: Fat reduction, muscle loss, central obesity increase, functional decline and worsening of plasma oxidative stress were observed during 2-year follow-up. Some of the risk factors that were identified could be modified to help prevent functional decline in elderly. The factors deserving attention include hypertension, arthritis/arthrosis and depression.
\end{abstract}

(c) 2016 Elsevier Ireland Ltd. All rights reserved.

\section{Introduction}

The Brazilian aging population has increased rapidly and is expected to reach the rank of the sixth country most elderly populous by 2025 (WHO, 2005). Aging process is characterized by reducing both lean mass (muscle, bone and water) as the fat mass

\footnotetext{
is Institution address where the work was done: Department of Internal Medicine. Botucatu Medical School, Sao Paulo State University (UNESP), Botucatu, SP, Brazil. CEP: 18618-970, Brazil. Tel./Fax: +55 143880 1171/+55 1438822238.

* Corresponding author.

E-mail addresses: pri_moreira@yahoo.com.br (P.L. Moreira), correa.camila9@gmail.com (C.R. Correa), jecorren@ibb.unesp.br (J.E. Corrente), cuadrado@fmb.unesp.br (L.C. Martin), pvboas@fmb.unesp.br (P.J.F.V. Boas), ferreira@fmb.unesp.br (A.L.A. Ferreira).
}

(Marucci, Alves \& Gomes, 2011). The process is also accompanied by occurrence of chronic diseases and progressive limitations in functional performance (Alves et al., 2007; Ramirez-Tortosa et al., 2004). Due to the dramatic increase in number of elderly, the prevalence of dependence is expected to increases as well. The prevention or even delay of the independence loss has significant implications in cost to the state and in the quality of old individuals's lives (Guralnik, Alecxih, Branch, \& Wiener, 2002). Therefore, it is important to identified modifiable risk factors to avoid functional decline.

Disability is defined as 'any restriction or lack (resulting from an impairment) of ability to perform an activity in the manner or within the range considered for a human being' (WHO, 1980). Functional disability is often measured by self-reports from people who either need help or have difficulty with basic activities (ADL) 
(Katz, Ford, Moskowitz, Jackson, \& Jaffe, 1963) and instrumental activities of daily living (IADL) (Freedman, Martin \& Schoeni, 2002; Lawton \& Brody, 1969). These validated scales allow exploring a wide range of physical, biological and psychological functions and reflect the level of dependence (Gallucci et al., 2011).

Functional incapacity has been associated with various factors, such as specific chronic diseases (Balzi et al., 2010; Nascimento et al., 2012), sociodemographic characteristics (Nascimento et al., 2012), changes in body composition (Larrieu et al., 2004; Moreira \& Boas, 2011; Nam, Kuo, Markides, \& Al Snih, 2012) and blood oxidative stress markers (Alipanah et al., 2009; Bartali et al., 2008; Cesari et al., 2006; Saito et al., 2012).

Smoking (Stuck et al., 1999), low education (Rodrigues, Facchini, Thume, \& Maia, 2013), age (Balzi et al., 2010; den Ouden, Schuurmans, Mueller-Schotte et al., 2013; Rodrigues et al., 2009), female gender (den Ouden et al., 2013), depression symptoms (Lêng \& Wang, 2013; Rodríguez López, Montero, Carmenate, \& Avendano, 2013; Stuck et al., 1999), hypertension (Balzi et al., 2010; Rodríguez López et al., 2013) and arthritis (den Ouden et al., 2013) are factors that have also been linked to functional decline in follow-up studies. However, to the best of our knowledge, the present study is the first to investigate the relationship among anthropometric measurements, functional capacity scores, socioeconomic status, medical conditions and blood oxidative stress markers in community-dwelling elderly. Therefore, the aim of the present study was to examine the changes and relationships among anthropometric, functional capacity (ADL and IADL), plasma oxidative stress markers ( $\beta$-carotene, $\alpha$-tocopherol and malondialdehyde), medical conditions, sociodemographic characteristics of elderly from a Brazilian city in 2-year follow-up study.

\section{Participants and methods}

The study was conducted in Botucatu (130,201 inhabitants) (IBGE, 2012) located $\left(22^{\circ} 53^{\prime} 09^{\prime \prime}\right.$ south latitude, $48^{\circ} 26^{\prime} 42^{\prime \prime}$ west longitude) in the Sao Paulo state, Brazil. The study consisted in a reevaluation in 2010 (Moment 2010) of a community-living elderly group assessed in 2008 (Moment 2008) (Moreira, Corrente, Boas, \& Ferreira, 2014). Two-year follow-up was chosen according to previous study with elderly people (Enoki et al., 2007; Ramos, Simoes, \& Albert, 2001) whose results showed that functional decline, anthropometric changes and mortality were correlated in a 2-year period.

The 2008 sample (base sample) was obtained from a database of a previous study conducted in Botucatu (Joia, Ruiz \& Donalisio, 2007). From the database sample of 365 elderly, 185 subjects were randomly selected to be part of the current study database. Fifty-nine subjects were excluded due to several reasons (refusal to participate in the study, 34; unanswered phone, 13; death, 3; use of vitamins, 3; absence of records on their medical conditions, 3; hospitalization, 2; absence, 1 ), and therefore, 126 remained in Moment 2008. In Moment 2010, 23 subjects were excluded (refusal to participate in the study, 12; unanswered phone, 7; death, 4) and therefore, 103 subjects were reassessed. Inclusion criteria were pre-defined as follow: residing in a community (city of Botucatu, SP, Brazil), $\geq 60$ years old and agreeing to participate in the study. Data were collected from May to November 2008 (Moment 2008) and from August 2010 to February 2011 (Moment 2010). The initial contact occurred by telephone, followed by a household interview, anthropometric measurements and blood draw. Data collections were done by an only trained interviewer in both moments. All procedures were in accordance with the Helsinki Declaration for human rights, and the study was approved (\#374/2009) by the Research Ethics Committee of the Botucatu
Medical School at Sao Paulo State University (UNESP). All patients or their legal guardians signed a Free-Consent form.

\subsection{Laboratorial analyses}

Fasting fresh serum was collected for determination of albumin $(\mathrm{g} / \mathrm{dL})$, glucose $(\mathrm{mg} / \mathrm{dL})$, triglycerides $(\mathrm{mg} / \mathrm{dL})$, total cholesterol and its fractions $(\mathrm{mg} / \mathrm{dL})$. The analyses were performed on automated equipment by standard dry chemistry methodology (Vitros 950, Johnson \& Johnson, Raritan, NJ, USA).

Fasting plasma was obtained and storage at $-80^{\circ} \mathrm{C}$ until analyses (maximum 6 months) of oxidative stress biomarkers. Alpha-tocopherol and $\beta$-carotene (Ferreira et al., 2000; Yeum et al., 1995) and malondialdehyde (MDA) (Karatas, Karatepe \& Baysar, 2002; Nielsen, Mikkelsen, Nielsen, Andersen, \& Grandjean, 1997) were determined according to previous studies by high performance liquid chromatography (Waters Alliance 2695, Waters, Wilmington, MA, USA). Every procedure was done protected from light. The $\alpha$-tocopherol, $\beta$-carotene and MDA were analyzed in two moments (2008 and 2010). The samples from the two moments were compared using values as a percentage relative to the maximum value ( $\mu \mathrm{mol} / \mathrm{L}$ ) obtained in each moment (Table 1 ). This procedure was adopted due to the fact that different HPLC systems were used in the two moments. The results from Moment 2008 are presented as real value ( $\mu \mathrm{mol} / \mathrm{L}$ ) (Tables 3 and 4 ).

\subsection{Anthropometric indicators and dietary intakes}

Weight and height were measured and BMI was calculated as weight/height ${ }^{2}\left(\mathrm{~kg} / \mathrm{m}^{2}\right)$ and classified as low weight $(\leq 23)$, ideal (23-28) and overweight $(\geq 28)$ (OPAS, 2003). For bedridden, weight and height were estimated according to established formulas (Chumlea, Guo, Roche, \& Steinbaugh, 1988; Chumlea \& Guo, 1992). Triceps (TSF) and subscapular skinfold thickness (SSF), Waist (WC), hip (HC), arm (AC) and calf (CC) circumferences were measured according to previous reports (Lohman, Roche \& Martorell, 1998). The waist-to-hip ratio (WHR) was calculated and the values were utilized to define elevated risk criteria for cardiovascular complication (1.00 for men and 0.85 for women), as suggested by the World Health Organization (WHO, 1997). The

\section{Table 1}

Anthropometric indicators, functional capacity and oxidative stress markers variation between 2008 and 2010.

\begin{tabular}{lccc}
\hline Variables $^{\mathrm{a}}$ & 2008 & 2010 & $p$-value \\
& Mean $( \pm \mathrm{SD})$ & & \\
\hline Weight $(\mathrm{kg})$ & $71.05(14.96)$ & $70.59(15.66)$ & 0.04 \\
Height $(\mathrm{m})$ & $1.61(0.09)$ & $1.61(0.09)$ & 0.77 \\
BMI $\left(\mathrm{kg} / \mathrm{m}^{2}\right)$ & $27.21(4.90)$ & $27.10(4.89)$ & 0.30 \\
CC $(\mathrm{cm})$ & $36.82(3.38)$ & $35.99(3.41)$ & $<0.0001$ \\
WC $(\mathrm{cm})$ & $93.85(12.77)$ & $95.82(12.49)$ & 0.0002 \\
HC $(\mathrm{cm})$ & $104.85(10.89)$ & $104.79(11.26)$ & 0.77 \\
WHR & $0.90(0.09)$ & $0.92(0.09)$ & $<0.0001$ \\
AC $(\mathrm{cm})$ & $32.01(4.01)$ & $31.40(4.19)$ & 0.004 \\
TSF $(\mathrm{mm})$ & $17.07(7.17)$ & $15.67(6.37)$ & 0.002 \\
SSF $(\mathrm{mm})$ & $14.86(3.96)$ & $14.43(3.89)$ & 0.56 \\
AMAc $\left(\mathrm{cm}{ }^{2}\right)$ & $48.65(11.96)$ & $47.55(12.34)$ & 0.11 \\
ADL & $5.73(0.82)$ & $5.52(0.89)$ & 0.0001 \\
IADL & $22.74(2.68)$ & $22.10(3.46)$ & 0.002 \\
$\beta$-carotene $(\%)^{\mathrm{b}}$ & $28.90(19.96)$ & $29.79(22.36)$ & 0.58 \\
$\alpha$-tocopherol $(\%)^{\mathrm{b}}$ & $52.74(18.82)$ & $26.87(16.80)$ & $<0.0001$ \\
MDA $(\%)^{\mathrm{b}}$ & $31.87(18.05)$ & $54.56(19.70)$ & $<0.0001$ \\
\hline
\end{tabular}

BMI: body mass index; CC: calf circunference; WC: waist circunference; HC: hip circumference; WHR: waist-to-hip ratio; AC: arm circunference; TSF: triceps skinfold thickness; SSF: subscapular skinfold thickness; AMAc: corrected arm muscle area; ADL: basic activities of daily living; IADL: instrumental activities of daily living; MDA: malondialdehyde

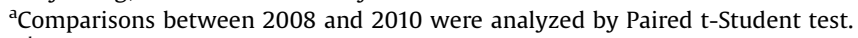

b Percentage relative to the maximum value obtained in 2008 and in 2010 . 
corrected arm muscle area (AMAc) was calculated by established formulas (Heymsfield, McManus, Smith, Stevens, \& Nixon, 1982). The evaluation of estimated daily intake was performed according to previous study (Moreira, Corrente et al., 2014).

\subsection{Socioeconomic status and medical conditions}

Subjects were questioned about current income (2008: basic salary, R\$ 415.00, US\$ 219.71; 2010: basic salary, R\$ 510.00, US\$ 301.46), schooling (number of years at school), companion at the home (yes or no), smoking habit (yes: current/former or no: absence) and self-reported diseases (yes or no). The presence of diseases was assessed with a series of questions to the subjects asking if a doctor had told them about medical conditions. Hypertension, arthritis, diabetes mellitus, depression, and arthritis/arthrosis and osteoporosis were the most prevalent selfreported diseases.

\subsection{Functional status measurements}

Self-reported measures of disability included activities of daily living (ADLs) (Katz et al., 1963) and instrumental activities of daily living (IADLs) (Lawton \& Brody, 1969). Individuals were defined as presenting difficulty if an affirmative response was given to at least one of the questions referring to difficulties in performing ADL and IADL (Amigues et al., 2013; Balzi et al., 2010; Nam et al., 2012; Ramsay, Whincup, Morris, Lennon, \& Wannamethee, 2008; Sánchez-García et al., 2014). The ADL scale (range 0-6) (low value indicates high impairment) was composed by the following tasks: eating, dressing, moving (from/to bed, chair or stand position), personal hygiene, urinary continence and use of toilet. The IADL scale (range 0-24) (low value indicates high impairment) was composed by the following tasks: telephone use, use of transportation, shopping, meal preparation, housekeeping, washing clothes, manual work (as craft, gardening etc.) and responsibility for medication intake.

\subsection{Statistical analyses}

The variable values (anthropometric indicators, functional capacity, energy [kcal] intake, fruit/vegetable intake, laboratorial analyses, income, education and functional capacity [ADL and IADL]) were described in quantitative variables and expressed as mean and standard deviation $( \pm S D)$ or median and percentiles (p25-p75). For gender, self-reported diseases, companion at home, income and smoking were described in frequencies and percentages. Comparisons between groups (with and without functional decline) were analyzed by Wilcoxon, Chi-square or Student $t$-test.

Group (Moments 2008 and 2010) differences in anthropometric characteristics, functional capacity and oxidative stress marker were analyzed by paired t-Student test. Chi-square test was used for comparison between proportions.

Multiple logistic regression model was used considering impairment of functional capacity (ADL and IADL) as variable response; and anthropometric, biochemical, socioeconomic, self- reported diseases and oxidative stress as independent variables, using a stepwise variable selection method, corrected for BMI, WC, Kcal, smoking and fruits/vegetables intakes. Data were analyzed using SAS for Windows software, v.9.2 (Cary, NC, USA). In all tests significance level was $5 \%$.

\section{Results}

Among the 103 included subjects, 60 (58.2\%) were women. The age population ranged from 67 to $92 \mathrm{y}(76.3 \pm 5.95)$. Body weight, CC, AC, TSF, ADL and IADL scores decreased and WC and WHR increased from 2008 to 2010. Alpha-tocopherol decreased and the malondialdehyde plasma levels increased during the two moments (Table 1). It was also identified that the percentage of overweight elderly persons (IMC $\geq 28 \mathrm{~kg} / \mathrm{m}^{2}$ ) was lower in 2010 (35.6\%) than in 2008 (38.8\%).

For ADL, 22 subjects (women, 14; men, 8) worsened, 3 improved and 78 maintained the same score between 2008 and 2010. For IADL, 28 individuals (women, 19; men, 9) worsened, 7 improved and 68 maintained the same score between 2008 and 2010. Although the IMC measured in 2008 did not significantly interfere on functional capacity of 2010, it was observed that subjects classified as low weight in 2008 (total, 7; IADL, 40\% vs. ADL, 6.7\%) showed in 2010 a more prevalent IADL compared to ADL (IADL $v s$. $A D L$ ). It was also verified for overweight elderly people (IADL, $34.2 \%$ vs. ADL, 23.7\%), although the difference between disabilities (IADL vs. ADL) is low (Table 2).

Subjects who developed impairment for ADL in 2010 were older and had low IADL score in 2008 (Table 3). Elderly who developed impairment for IADL in 2010 were older, had low education, hypertension, depression, arthritis/arthrosis and ADL and IADL low scores in 2008 (Table 4).

In multiple logistic regression analyses, increased age, female gender were independent risk factors for functional IADL decline. Absence of hypertension and arthritis/arthrosis were independent protector risk factors for functional IADL decline. The same was identified for absence of depression, although it was of marginal significance $(p=0.05)$ (Table 5). Absence of risk factors were identified for ADL (data not shown).

\section{Discussion}

Our results showed that elderly displayed muscle mass loss (AC and $C C$ ), adipose tissue reduction (AC and TSF), functional decline (ADL and IADL) and worsening of oxidative stress (decrease in $\alpha$-tocopherol and increase in MDA) in a two-year follow-up. An increase in central obesity (WC and WHR) was also identified. Increased age, being female, absence of hypertension, arthritis/ arthrosis and depression were independent risk factors for functional IADL decline.

Several longitudinal studies evaluated Brazilian elderly (Figueiredo, Assis, Silva, Dias, \& Mancini, 2013; Lima e Costa et al., 2000; Lebrão \& Duarte, 2003; Maciel \& Guerra, 2010; Ramos, 2003; Santos, Dantas \& Moreira, 2011). However, these studies have not evaluated the association among the variables like the current

Table 2

BMI classification in 2008 of the subjects that developed functional decline in 2010.

\begin{tabular}{|c|c|c|c|c|}
\hline \multirow[t]{2}{*}{ Funcional Decline (2008-2010) } & \multicolumn{3}{|c|}{ BMI classification in 2008} & \multirow[t]{2}{*}{$p$-value ${ }^{a}$} \\
\hline & Low weight $(n=15)$ & Ideal $(n=50)$ & Overweight $(\mathrm{n}=38)$ & \\
\hline ADL & $1(6.7 \%)$ & $12(24.0 \%)$ & $9(23.7 \%)$ & 0.3234 \\
\hline IADL & $6(40.0 \%)$ & $9(18.0 \%)$ & $13(34.2 \%)$ & 0.1152 \\
\hline
\end{tabular}

Values represent number of subjects (percentage); BMI: body mass index; ADL: basic activities of daily living; IADL: instrumental activities of daily living

${ }^{a}$ comparisons among BMI classifications were analyzed by chi-square test. 
Table 3

Main characteristics of the study sample in 2008 that developed or not ADL decline in 2010.

\begin{tabular}{|c|c|c|c|}
\hline \multirow[t]{2}{*}{ Variables } & \multicolumn{2}{|l|}{ ADL decline } & \multirow[t]{2}{*}{$p$-value ${ }^{a}$} \\
\hline & Yes $(n=22)$ & No $(n=81)$ & \\
\hline Age $(y)$, mean $( \pm S D)^{2}$ & $78.54(6.60)$ & $75.64(5.64)$ & 0.04 \\
\hline Gender (women), n (\%) ${ }^{3}$ & $14(23.3)$ & $46(76.6)$ & 0.56 \\
\hline Hypertension, $\mathrm{n}(\%)^{3}$ & $11(23.4)$ & $36(76.6)$ & 0.64 \\
\hline Arthritis/Arthrosis, $\mathrm{n}(\%)^{3}$ & $1(14.3)$ & $6(85.7)$ & 1.00 \\
\hline Diabetes mellitus, $\mathrm{n}(\%)^{3}$ & $4(18.2)$ & $18(81.8)$ & 0.68 \\
\hline Osteoporosis, n (\%) & $2(16.7)$ & $10(83.3)$ & 0.67 \\
\hline Depression, $\mathrm{n}(\%)^{3}$ & $5(35.7)$ & $9(64.2)$ & 0.15 \\
\hline Living alone, $\mathrm{n}(\%)^{3}$ & $3(21.4)$ & $11(78.6)$ & 0.99 \\
\hline Smoking $\mathrm{n}(\%)^{3}$ & $1(9.1)$ & $10(90.9)$ & 0.41 \\
\hline Income (<4 BS), $\mathrm{n}(\%)^{3}$ & $8(16.3)$ & $41(83.6)$ & 0.23 \\
\hline Schooling years, mean $( \pm S D)^{2}$ & $6.77(5.03)$ & $6.35(4.78)$ & 0.71 \\
\hline $\mathrm{BMI}\left(\mathrm{Kg} / \mathrm{m}^{2}\right)$, mean $\pm \mathrm{SD}^{2}$ & $28.29(6.00)$ & $26.91(4.54)$ & 0.24 \\
\hline $\mathrm{WC}(\mathrm{cm})$, mean $\pm \mathrm{SD}^{2}$ & $94.70(15.44)$ & $93.61(12.04)$ & 0.72 \\
\hline WHR, mean $\pm S^{2}$ & $0.88(0.08)$ & $0.89(0.09)$ & 0.49 \\
\hline $\mathrm{AC}(\mathrm{cm})$, mean $( \pm \mathrm{SD})^{2}$ & $32.45(4.66)$ & $31.89(3.84)$ & 0.56 \\
\hline $\operatorname{TSF}(\mathrm{mm})$, mean $( \pm \mathrm{SD})^{2}$ & $17.27(6.63)$ & $17.01(7.34)$ & 0.88 \\
\hline AMA $\left(\mathrm{cm}^{2}\right)$, mean $( \pm S D)^{2}$ & $48.29(11.45)$ & $48.74(12.15)$ & 0.87 \\
\hline $\mathrm{CC}(\mathrm{cm})$, mean $( \pm \mathrm{SD})^{2}$ & $37.84(3.62)$ & $36.49(3.25)$ & 0.10 \\
\hline Kcal, mean $( \pm S D)^{2}$ & $2280.7(626.2)$ & $2382.7(801.6)$ & 0.58 \\
\hline Fruit/veget intake $(\mathrm{g})$, mean $( \pm S D)^{2}$ & $687.70(277.40)$ & $664.50(331.70)$ & 0.57 \\
\hline ADL, median $(25 \text { th }-75 \text { th })^{4}$ & $6(6-6)$ & $6(6-6)$ & 0.27 \\
\hline IADL, median (25th-75th) ${ }^{4}$ & $24(21-24)$ & $24(24-24)$ & 0.002 \\
\hline Albumin $(\mathrm{g} / \mathrm{dL})$, mean $( \pm \mathrm{SD})^{2}$ & $3.96(0.33)$ & $3.98(0.33)$ & 0.81 \\
\hline Total chol $(\mathrm{mg} / \mathrm{dL})$, mean $( \pm \mathrm{SD})^{2}$ & $179.9(28.73)$ & $194.6(36.23)$ & 0.08 \\
\hline HDL-chol $(\mathrm{mg} / \mathrm{dL})$, mean $( \pm \mathrm{SD})^{2}$ & $48.65(14.59)$ & $48.97(14.62)$ & 0.93 \\
\hline LDL-chol $(\mathrm{mg} / \mathrm{dL})$, mean $( \pm \mathrm{SD})^{2}$ & $104.5(29.63)$ & $114.4(32.79)$ & 0.22 \\
\hline $\operatorname{Tg}(\mathrm{mg} / \mathrm{dL})$, mean $( \pm \mathrm{SD})^{2}$ & $125.5(54.64)$ & $150.2(81.58)$ & 0.20 \\
\hline Glucose $(\mathrm{mg} / \mathrm{dL})$, mean $( \pm \mathrm{SD})^{2}$ & $90.90(18.11)$ & $99.82(43.28)$ & 0.15 \\
\hline$\beta$-carotene $(\mu \mathrm{mol} / \mathrm{L})$, mean $( \pm \mathrm{SD})^{2}$ & $0.10(0.07)$ & $0.11(0.08)$ & 0.47 \\
\hline$\alpha$-tocopherol $(\mu \mathrm{mol} / \mathrm{L})$, mean $( \pm \mathrm{SD})^{2}$ & $12.66(3.74)$ & $13.07(4.86)$ & 0.71 \\
\hline $\operatorname{MDA}(\mu \mathrm{mol} / \mathrm{L})$, mean $( \pm \mathrm{SD})^{2}$ & $0.84(0.46)$ & $0.83(0.47)$ & 0.95 \\
\hline
\end{tabular}

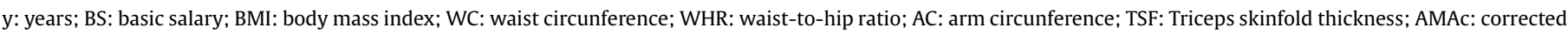

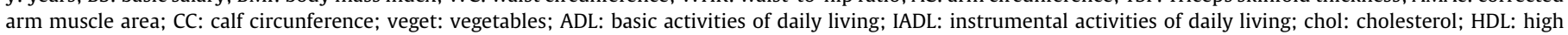
density lipoprotein; LDL: low density lipoprotein; Tg: triglycerides; MDA: malondialdehyde; ${ }^{2,3, a n d 4}$ : analyzed by Student $t$ (2), chi-square (3) and Wilcoxon tests (4).

a Adjusted by BMI, WC, Kcal, ingestion of fruit/vegetable and current smoking.

study and none of them assessed oxidative stress. To the best of our knowledge, this is the first study to evaluate jointly the anthropometric variables, functional capacity (ADL and IADL), socioeconomic status, health habits and oxidative stress markers ( $\beta$-carotene, $\alpha$-tocopherol and MDA) in Brazilian communitydwelling elderly.

The decrease in weight, BMI, CC (Almeida et al., 2013), TST (Almeida et al., 2013; Hughes et al., 2004), SSF (Hughes et al., 2004), AC (Almeida et al., 2013; Enoki et al., 2007; Hughes et al., 2004) and AMB (Almeida et al., 2013; Enoki et al., 2007) were also identified in other follow-up studies, corroborating our findings. The decrease in AMA $(p>0.05)$ and TSF $(p<0.05)$ presently observed were predictors of mortality in 2-y follow-up in Japanese population (Enoki et al., 2007). The decrease in AC seen in our results was associated with mortality from all causes in 6-y followup study of European population (Hollander, Bemelmans \& Groot, 2013). The increased WC and WHR also identified by other researchers (Almeida et al., 2013; Genton et al., 2011), amplified the chance of functional decline for both ADL and IADL in 9-y follow-up in older Americans (Houston, Stevens, \& Cai, 2005). However, a study conducted in São Paulo-SP (6-y follow-up) showed reduction in WC and WHR (Almeida et al., 2013). The fact that we found increasing values of these anthropometric variables (WC e WHR) can be partly explained by the redistribution of body fat that occurs in aging (Ding et al., 2007; Chang, Beason, Hunleth, \& Colditz, 2012; Michalakis et al., 2013). BMI maintenance for two years [2008 $(27.21 \pm 4.90)$ vs. $2010(27.10 \pm 4.89), \mathrm{p}=0.30]$ and the lack of association between the index and functional decline (ADL and IADL) suggest that the maintenance of weight within the normal range (BMI $23-28 \mathrm{~kg} / \mathrm{m}^{2}$ ) should be encouraged among elderly (Moreira, Boas \& Ferreira, 2014). Another longitudinal study (5-y follow-up) examining older French also found similar results where the lowest functional decline (IADL) was associated with adequate BMI $\left(23-27 \mathrm{~kg} / \mathrm{m}^{2}\right)$ (Deschamps et al., 2002).

The functional decline observed for both ADL and IADL parameters was previously identified by follow-up studies in 6 months (Figueiredo et al., 2013), 2 years (Lee, Kim, Back, Kim, \& Ryu, 2013; Menezes, Bachion, Souza, \& Nakatani, 2011), 3 years (Balzi et al., 2010; Bartali et al., 2006), 4 years (Amigues et al., 2013) and 6 years (Alexandre et al., 2012). In contrast, longitudinal Brazilian study found improvement in functional capacity (measured by the $100-\mathrm{m}$ walking test) in the elderly from several cities analyzed by the National Research by Household Sample (Pesquisa Nacional por Amostras de Domicílio, PNAD) from 1998 to 2003. Some factors that may have contributed to this result were improvement of education, health service accessibility, medical technology development and socioeconomic conditions (Parahyba \& Veras, 2008).

Little is known about the diet role on preventing functional disability, although the effect of diet on chronic disease prevention is well established. We identified lower fruit and vegetable intake [mean $( \pm \mathrm{SD}), \mathrm{g} /$ day] in individuals who have experienced IADL decline [607.3 (258.7)] as compared to those who didn't have it [671.0 (340.2)], even though this difference was not significant $(p=0.37)$. Antioxidants in fruits and vegetables may prevent oxidative stress damage and, thus, decrease the risk of functional decline (Cesari et al., 2004). Examining 787 older Koreans, recent cross-sectional study showed that high fruit and vegetable intake was associated with low risk for ADL and IADL disability (Kim et al., 2013). Similar results were observed in a biracial cohort study 
Table 4

Main characteristics of the study sample in 2008 that developed or not IADL decline in 2010.

\begin{tabular}{|c|c|c|c|}
\hline \multirow[t]{2}{*}{ Variables } & \multicolumn{2}{|l|}{ IADL decline } & \multirow{2}{*}{$\begin{array}{l}p- \\
\text { value }^{a}\end{array}$} \\
\hline & Yes $(n=28)$ & No $(n=75)$ & \\
\hline Age $(y)$, mean $( \pm S D)^{2}$ & $79.25(4.67)$ & $75.14(6.01)$ & 0.001 \\
\hline Gender (women), n (\%) ${ }^{3}$ & $19(31.6)$ & $41(68.3)$ & 0.22 \\
\hline Hypertension, $\mathrm{n}(\%)^{3}$ & $18(38.3)$ & $29(61.7)$ & 0.02 \\
\hline Arthritis/Arthrosis, n (\%) ${ }^{3}$ & $5(71.4)$ & $2(28.6)$ & 0.006 \\
\hline Diabetes mellitus, $\mathrm{n}(\%)^{3}$ & $8(36.3)$ & $14(63.6)$ & 0.27 \\
\hline Osteoporosis, n (\%) $)^{3}$ & $2(16.7)$ & $10(83.3)$ & 0.38 \\
\hline Depression, $\mathrm{n}(\%)^{3}$ & $7(50)$ & $7(50)$ & 0.03 \\
\hline Living alone, $\mathrm{n}(\%)^{3}$ & $1(7.1)$ & $13(92.9)$ & 0.10 \\
\hline Smoking $\mathrm{n}(\%)^{3}$ & $2(18.2)$ & $9(81.8)$ & 0.74 \\
\hline Income $(<4 \mathrm{BS}), \mathrm{n}(\%)^{3}$ & $15(30.6)$ & $34(69.4)$ & 0.46 \\
\hline Schooling years, mean $( \pm \mathrm{SD})^{2}$ & $4.61(4.23)$ & $7.12(4.86)$ & 0.02 \\
\hline BMI $\left(\mathrm{Kg} / \mathrm{m}^{2}\right)$, mean $\pm \mathrm{SD}^{2}$ & $27.72(5.85)$ & $27.01(4.51)$ & 0.51 \\
\hline $\mathrm{WC}(\mathrm{cm})$, mean $\pm \mathrm{SD}^{2}$ & 95.75 (14.09) & $93.14(12.26)$ & 0.35 \\
\hline $\mathrm{WHR}$, mean $\pm \mathrm{SD}^{2}$ & $0.89(0.08)$ & $0.89(0.09)$ & 0.94 \\
\hline $\mathrm{AC}(\mathrm{cm})$, mean $( \pm \mathrm{SD})^{2}$ & $31.87(4.40)$ & $32.06(3.88)$ & 0.83 \\
\hline $\operatorname{TSF}(\mathrm{mm})$, mean $( \pm \mathrm{SD})^{2}$ & $17.88(8.06)$ & $16.75(6.82)$ & 0.47 \\
\hline AMA $\left(\mathrm{cm}^{2}\right)$, mean $( \pm S D)^{2}$ & 47.99 (12.79) & $48.90(11.70)$ & 0.73 \\
\hline $\mathrm{CC}(\mathrm{cm})$, mean $( \pm \mathrm{SD})^{2}$ & $37.18(4.29)$ & $36.66(2.92)$ & 0.57 \\
\hline Kcal, mean $( \pm \mathrm{SD})^{2}$ & $\begin{array}{l}2395.3 \\
(747.9)\end{array}$ & $\begin{array}{l}2348.1 \\
(777.0)\end{array}$ & 0.78 \\
\hline Fruit/veget intake $(\mathrm{g})$, mean $( \pm S D)^{2}$ & $607.3(258.7)$ & $671.0(340.2)$ & 0.37 \\
\hline ADL, median (25th-75th) ${ }^{4}$ & $6(5-6)$ & $6(6-6)$ & 0.002 \\
\hline IADL, median (25th-75th) ${ }^{4}$ & $22(19.5-24)$ & $24(24-24)$ & $<0.001$ \\
\hline Albumin $(\mathrm{g} / \mathrm{dL})$, mean $( \pm \mathrm{SD})^{2}$ & $3.90(0.40)$ & $4.01(0.29)$ & 0.18 \\
\hline Total chol $(\mathrm{mg} / \mathrm{dL})$, mean $( \pm \mathrm{SD})^{2}$ & $181.1(32.61)$ & $195.4(35.49)$ & 0.06 \\
\hline HDL-chol $(\mathrm{mg} / \mathrm{dL})$, mean $( \pm \mathrm{SD})^{2}$ & $47.07(15.05)$ & $49.62(14.38)$ & 0.44 \\
\hline LDL-chol $(\mathrm{mg} / \mathrm{dL})$, mean $( \pm \mathrm{SD})^{2}$ & $105.8(29.46)$ & $114.9(33.15)$ & 0.21 \\
\hline $\operatorname{Tg}(\mathrm{mg} / \mathrm{dL})$, mean $( \pm \mathrm{SD})^{2}$ & $145.0(62.33)$ & $145.1(82.65)$ & 0.99 \\
\hline Glucose $(\mathrm{mg} / \mathrm{dL})$, mean $( \pm \mathrm{SD})^{2}$ & $100.8(39.7)$ & $96.86(39.47)$ & 0.65 \\
\hline$\beta$-carotene $(\mu \mathrm{mol} / \mathrm{L})$, mean $( \pm \mathrm{SD})^{2}$ & $0.09(0.06)$ & $0.11(0.08)$ & 0.16 \\
\hline$\alpha$-tocopherol $(\mu \mathrm{mol} / \mathrm{L})$, mean $( \pm \mathrm{SD})^{2}$ & $12.57(4.99)$ & $13.14(4.51)$ & 0.58 \\
\hline $\operatorname{MDA}(\mu \mathrm{mol} / \mathrm{L})$, mean $( \pm \mathrm{SD})^{2}$ & $0.81(0.46)$ & $0.84(0.47)$ & 0.80 \\
\hline
\end{tabular}

y: years; BS: basic salary; BMI: body mass index; WC: waist circunference; WHR: waist-to-hip ratio; AC: arm circunference; TSF: Triceps skinfold thickness; AMAc: corrected arm muscle area; CC: calf circunference; veget: vegetables; ADL: basic activities of daily living; IADL: instrumental activities of daily living; chol: cholesterol; HDL: high density lipoprotein; LDL: low density lipoprotein; Tg: triglycerides; MDA: malondialdehyde; ${ }^{2,3, \text { and } 4}$ : analyzed by Student $t$-test (2), chisquare (3) and Wilcoxon (4).

a Adjusted by BMI, WC, Kcal, ingestion of fruit/vegetable and current smoking.

(9-y follow-up) with American men and women (45-64y) (Houston, Stevens, Cai, \& Haines, 2005). The lack of significance in the present study can be partly explained by short interval between the two analyses.

There was no association between functional decline and socioeconomic indicators, blood glucose, lipid profile, albumin and oxidative stress markers in our analyses. On the other hand, previous study described that low levels of serum albumin and total cholesterol were associated with mortality and ADL decline in a longitudinal study (12-y follow-up) conducted in older Japanese

Table 5

Multiple logistic regression of promoting factors for IADL decline.

\begin{tabular}{llcc}
\hline Variables $^{\mathrm{a}}$ & \multicolumn{2}{l}{ IADL $^{\mathrm{b}}$} & \multirow{2}{*}{$p$-value } \\
\cline { 2 - 3 } & OR & IC 95\% & \\
\hline Age & 1.12 & $1.02-1.23$ & 0.02 \\
Sex & 8.43 & $1.23-57.58$ & 0.03 \\
Hypertension & 0.22 & $0.06-0.79$ & 0.02 \\
Arthritis/Arthrosis & 0.09 & $0.009-0.87$ & 0.04 \\
Depression & 0.20 & $0.04-1.03$ & 0.05 \\
\hline
\end{tabular}

a Adjusted by BMI, WC, smoking, and ingestion of fruit/vegetable and Kcal.

b Model containing all variables in Table 2; age: the older the subject, the greater the risk for the development of IADL decline; sex: being female means increased odds ratio for the development of IADL decline; Hypertension, Depression, arthritis/ arthrosis (absence $v s$. presence of disease): absence of the condition means lower odds ratio for the development of IADL decline.
(Okamura et al., 2008). In addition, smoking (Stuck et al., 1999) and low education (Rodrigues et al., 2009) have been associated with ADL and IADL declines in systematic reviews.

Defined as an event resulting from an imbalance between reactive species (reactive oxygen species, ROS and reactive nitrogen species, RNS) and antioxidant system, the oxidative stress has been appointed as an important mechanism associated with aging. Several markers measure the oxidation level in lipid, protein and DNA and others assess the antioxidant system content (Moreira, Boas et al., 2014). In the current study, it was evaluated the liposoluble antioxidants ( $\beta$-carotene and $\alpha$-tocopherol) and a lipid peroxidation product (MDA) in plasma. Oxidative stress, shown by the reduction of $\alpha$-tocopherol and increase of MDA, occurred at 2 year-follow-up. The lack of studies analyzing this issue in follow-up trials prevents further comparisons. Examining different age groups, previous studies have also identified the drop of $\alpha$-tocopherol (Mecocci et al., 2000) and the increase in MDA (İnal, Kanbak \& Sunal, 2001; Mezzetti et al., 1996; Mutlu-Türkoğlu et al., 2003; Massudi et al., 2012; Ozbay \& Dulger, 2002; Rizvi \& Maurya, 2007).

Association between functional decline and changes in plasma oxidative stress markers (MDA, $\alpha$-tocopherol and $\beta$-carotene) was not currently identified. Using larger interval between analyses, longitudinal studies have identified inverse association between functional decline and blood concentrations of carotenoids (Alipanah et al., 2009; Lauretani et al., 2008; Semba et al., 2007) and vitamin E (Bartali et al., 2008).

In multiple logistic regression analyses, increased age, female gender, hypertension, arthritis/arthrosis and depression were independent risk factors for functional IADL decline. No risk factors were identified for ADL decline in our study. Longitudinal trials and systematic reviews also identified predictive or risk factors for functional decline related to increased age (ADL, IADL) (Balzi et al., 2010; den Ouden et al., 2013; Rodrigues et al., 2009), female gender (ADL) (den Ouden et al., 2013), depression symptoms (Lêng \& Wang, 2013; Rodríguez López et al., 2013; Stuck et al., 1999), hypertension (ADL, IADL) (Balzi et al., 2010; Rodríguez López et al., 2013) and arthritis (ADL) (den Ouden et al., 2013).

In summary, our study showed that, elderly living in community presented muscle mass loss (AC and $C C$ ), reduction (AC, TSF) and redistribution (WC and WHR) of fat, functional decline (ADL and IADL) and worsening of oxidative stress plasma markers (decrease in $\alpha$-tocopherol and increase in MDA) in two year-follow-up. Additionally, increased age, female gender, hypertension, arthritis/arthrosis and depression were independent risk factors for functional decline (IADL).

The limitations of this study included its small sample size and short follow-up. The original base sample was 365 elderly and 185 were randomly selected. After exclusion, 126 participated on the Moment 2008 and 103 on the 2010. The short interval between assessments was chosen due to the quick nutritional and functional changes, the possibility of sample loss (as shown in our study where $3.2 \%$ of population died in the period) and therefore an urgency in the data analysis. On the other hand, longer evaluation interval might have helped to increase the significance of a some borderline associations. However, the observed associations were strong despite the short follow-up. New evaluations of the same population are needed in order to prevent worsening by applying specific health and social policies.

In spite of the limitations, the current study represents a contribution for the understanding of the effect of time on the functional capacity, anthropometric characteristics and oxidative stress markers and as well as the identification of associations among variables in the elderly living in the community. Researches with a larger number of individuals are needed to confirm these 
results and thus identify what are the most appropriate measures to prevent the institutionalization. Some of the risk factors, that we identified, could be prevented, treated or better controlled, so as to help decelerate functional decline in older. The factors deserving attention include hypertension, arthritis/arthrosis and depression.

\section{Conflicts of interest}

There is no conflict of interest declared.

\section{Acknowledgements}

We thank São Paulo Research Foundation (FAPESP) (grants \#2007/57545-8 and \#2007/07455-2), Coordenação de Aperfeiçoamento de Pessoal de Nível Superior (CAPES - doctoral Scholarship) and Fundação para o Desenvolvimento da UNESP (FUNDUNESP), which provided financial support for this survey. We also thank Research Support Group at Botucatu School of Medicine at Sao Paulo State University (UNESP), which helped in the statistical analysis. We appreciate Anita Modenese's editing of the English grammar.

São Paulo Research Foundation (FAPESP) grant \#2007/57545-8 (Master's Scholarship) and grant \#2007/07455-2 (Research Financial Support).

PLM performed the data collection. CRC advised laboratory methods. JEC and PLM worked on data analysis and interpretation, and statistical analysis. PJFVB, CRC, PLM, JEC, LCM and ALAF wrote the final version of the manuscript. All authors evaluated the results, contributed their comments, and approved the final version of the manuscript before submission for publication.

\section{References}

İnal, M. E., Kanbak, G., \& Sunal, E. (2001). Antioxidant enzyme activities and malondialdehyde levels related to aging. Clinica Chimica Acta, 305(1-2), 75-80. http://dx.doi.org/10.1016/S0009-8981(00)00422-8.

Alexandre, T. S., Corona, L. P., Nunes, D. P., Santos, J. L. F., Duarte, Y. A. O., \& Lebrão, M. L. (2012). Gender differences in incidence and determinants of disability in activities of daily living among elderly individuals: SABE study. Archives of Gerontology and Geriatrics, 55, 431-437. http://dx.doi.org/10.1016/j. archger.2012.04.001.

Alipanah, N., Varadhan, R., Sun, K., Ferrucci, L., Fried, L. P., \& Semba, R. D. (2009). Low serum carotenoids are associated with a decline in walking speed in older women. The Journal of Nutrition, Health \& Aging, 13(3), 170-175. http://dx.doi. org/10.1007/s12603-009-0053-6.

Almeida, M. F., Marucci, M. F. N., Gobbo, L. A., Ferreira, L. S., Dourado, D. A. Q. S. Duarte, Y. A. O., et al. (2013). Anthropometric changes in the brazilian cohort of older adults: SABE survey (health, well-being, and aging). Journal of Obesity. http://dx.doi.org/10.1155/2013/695496.

Alves, L. C., Leimann, B. C. O., Vasconcelos, M. E. L., Carvalho, M. S., Fonseca, T. C. O., Lebrão, M. L., et al. (2007). A influência das doenças crônicas na capacidade funcional dos idosos do Município de São Paulo. Brasil. Cadernos De Saúde Pública, 23(8), 1924-1930. http://dx.doi.org/10.1590/s0102$311 \times 2007000800019$.

Amigues, I., Schott, A. M., Amine, M., Gelas-Dore, B., Veerabudun, K., Paillaud, E., et al. (2013). Low skeletal muscle mass and risk of functional decline in elderly community-dwelling women: the prospective EPIDOS Study. Journal of the American Medical Directors Association, 14, 352-357. http://dx.doi.org/10.1016/j. jamda.2012.12.002.

Balzi, D., Lauretani, F., Barchielli, A., Ferrucci, L., Bandinelli, S., Buiatti, E., et al. (2010). Risk factors for disability in older persons over 3-year follow-up. Age and Ageing, 39, 92-98. http://dx.doi.org/10.1093/ageing/afp209.

Bartali, B., Semba, R. D., Frongillo, E. A., Varadhan, R., Ricks, M. O., Blaum, C. S., et al (2006). Low micronutrient levels as a predictor of incident disability in older women. Archives of Internal Medicine, 166, 2335-2340. http://dx.doi.org/ 10.1001/archinte.166.21.2335

Bartali, B., Frongillo, E. A., Guralnik, J. M., Stipanuk, M. H., Allore, H. G., Cherubini, A., et al. (2008). Serum micronutrient concentrations and decline in physical function among older persons. JAMA, 299(3), 308-315. http://dx.doi.org/ 10.1001/jama.299.3.308.

Cesari, M., Pahor, M., Bartali, B., Cherubini, A., Penninx, B. W., Williams, G. R., et al (2004). Antioxidants and physical performance in elderly persons: the Invecchiare in Chianti (InCHIANTI) study. The American Journal of Clinical Nutrition, 79, 289-294.

Cesari, M., Kritchevsky, S. B., Leeuwenburgh, C., \& Pahor, M. (2006). Oxidative damage and platelet activation as new predictors of mobility disability and mortality in elders. Antioxidants \& Redox Signaling, 8(3-4), 609-619. http://dx. doi.org/10.1089/ars.2006.8.609.

Chang, S.-H., Beason, T. S., Hunleth, J. M., \& Colditz, G. A. (2012). A systematic review of body fat distribution and mortality in older people. Maturitas, 72, 175-191. http://dx.doi.org/10.1016/j.maturitas.2012.04.004.

Chumlea, W. C., \& Guo, S. (1992). Equations for predictying stature in white and black elderly individuals. Journal of Gerontology, 47, 197-203. http://dx.doi.org/ 10.1093/geronj/47.6.M197.

Chumlea, W. C., Guo, S., Roche, A. F., \& Steinbaugh, M. L. (1988). Prediction of body weight for the nonambulatory elderly from anthropometry. Journal of the American Dietetic Association, 88(5), 565-568.

den Ouden, M. E., Schuurmans, M. J., Mueller-Schotte, S., \& van der Schouw, Y. T. (2013). Identification of high-risk individuals for the development of disability in activities of daily living. A ten-year follow-up study. Experimental Gerontology, 48, 437-443. http://dx.doi.org/10.1016/j.exger.2013.02.002.

Deschamps, V., Astier, X., Ferry, M., Rainfray, M., Emeriau, J. P., \& Barberger-Gateau, P. (2002). Nutritional status of healthy elderly persons living in Dordogne France, and relation with mortality and cognitive or functional decline. European Journal of Clinical Nutrition, 56, 305-312. http://dx.doi.org/10.1038/sj/ejcn/1601311.

Ding, J., Kritchevsky, S. B., Newman, A. B., Taaffe, D. R., Nicklas, B. J., Visser, M., et al. (2007). Effects of birth cohort and age on body composition in a sample of community-based elderly. The American Journal of Clinical Nutrition, 85, 405410.

Enoki, H., Kuzuya, M., Masuda, Y., Hirakawa, Y., Iwata, M., Hasegawa, J., et al. (2007). Anthropometric measurements of mid-upper arm as a mortality predictor for community-dwelling Japanese elderly: the Nagoya Longitudinal Study of Frail Elderly (NLS-FE). Clinical Nutrition, 26, 597-604. http://dx.doi.org/10.1016/j. clnu.2007.06.008.

Ferreira, A. L. A., Yeum, K. J., Liu, C., Smith, D., Krinsky, N. I., Wang, X. D., et al. (2000). Tissue distribution of lycopene in ferrets and rats after lycopene supplementation. The Journal of Nutrition, 130, 1256-1260.

Figueiredo, C. S., Assis, M. G., Silva, S. L., Dias, R. C., \& Mancini, M. C. (2013) Functional and cognitive changes in community-dwelling elderly: longitudinal study. Brazilian Journal of Physical Therapy, 17(3), 297-306. http://dx.doi.org/ 10.1590/S1413-35552012005000094.

Freedman, V. A., Martin, L. G., \& Schoeni, R. F. (2002). Recent trends in disability and functioning among older adults in the United States a systematic review. JAMA, 288(24), 3137-3146. http://dx.doi.org/10.1001/jama.288.24.3137.

Gallucci, M., Ongaro, F., Meggiolaro, S., Antuono, P., Gustafson, D. R., Forloni, G. L., et al. (2011). Factors related to disability: evidence from the "Treviso longeva (TRELONG) study. Archives of Gerontology and Geriatrics, 52, 309-316. http://dx. doi.org/10.1016/j.archger.2010.05.007.

Genton, L., Karsegard, V. L., Chevalley, T., Kossovsky, M. P., Darmon, P., \& Pichard, C. (2011). Body composition changes over 9 years in healthy elderly subjects and impact of physical activity. Clinical Nutrition, 30, 436-442. http://dx.doi.org/ 10.1016/j.clnu.2011.01.009.

Guralnik, J. M., Alecxih, L., Branch, L. G., \& Wiener, J. M. (2002). Medical and longterm care costs when older persons become more dependent. American Journal of Public Health, 92(8), 1244-1245.

Heymsfield, S. B., McManus, C., Smith, J., Stevens, V., \& Nixon, D. W. (1982) Anthropometrisc measurement of muscle mass: revised equations for calculating bone-free arm muscle area. The Americal Journal of Clinical Nutrition, 36, 680-690.

Hollander, E. L., Bemelmans, W. J. E., \& Groot, L. C. P. G. M. (2013). Associations between changes in anthropometric measures and mortality in old age: a role for mid-upper arm circumference? Journal of the American Medical Directors Association, 14, 187-193. http://dx.doi.org/10.1016/j.jamda.2012.09.023.

Houston, D. K., Stevens, J., Cai, J., \& Haines, P. S. (2005). Dairy, fruit: and vegetable intakes and functional limitations and disability in a biracial cohort: the atherosclerosis risk in communities study. The American Journal of Clinical Nutrition, 81, 515-522.

Houston, D. K., Stevens, J., \& Cai, J. (2005). Abdominal fat distribution and functional limitations and disability in a biracial cohort: the Atherosclerosis Risk in Communities Study. International Journal of Obesity, 29, 1457-1463. http://dx. doi.org/10.1038/sj.ijo.0803043.

Hughes, V. A., Roubenoff, R., Wood, M., Frontera, W. R., Evans, W. J., \& Fiatarone Singh, M. A. (2004). Anthropometric assessment of $10-\mathrm{y}$ changes in body composition in the elderly. The American Journal of Clinical Nutrition, 80, 475482 .

Instituto Brasileiro de Geografia e Estatística-IBGE, Diretoria de Pesquisas -DPE Coordenação de População e Indicadores Sociais COPIS (2012). Estimativa da população residente com data de referencia 1(de julho de 2012. Retrieved from http://www.ibge.gov.br/cidadesat/link.php? codmun=350750.

Joia, L. C., Ruiz, T., \& Donalisio, M. R. (2007). Life satisfaction among elderly population in the city of Botucatu, Southern Brazil. Revista de Saúde Pública, 41 (1), 131-138. http://dx.doi.org/10.1590/S0034-89102007000100018.

Karatas, F., Karatepe, M., \& Baysar, B. (2002). Determination of free malondialdehyde in human serum by high-performance liquid chromatography. Analytical Biochemistry, 311, 76-79.

Katz, S., Ford, A. B., Moskowitz, R. W., Jackson, B. A., \& Jaffe, M. W. (1963). Studies of illness in the aged-The index of ADL: a standardized measure of biological and psychosocial function. JAMA, 185, 914-919. http://dx.doi.org/10.1001/ jama.1963.03060120024016.

Kim, J., Lee, Y., Lee, S. Y., Kim, Y. O., Chung, Y. S., \& Park, S. B. (2013). Dietary patterns and functional disability in older Korean adults. Maturitas, 76, 160-164. http:// dx.doi.org/10.1016/j.maturitas.2013.07.011. 
Lêng, C. H., \& Wang, J. D. (2013). Long term determinants of functional decline of mobility: an 11-year follow-up of 5464 adults of late middle aged and elderly. Archives of Gerontology and Geriatrics, 57, 215-220. http://dx.doi.org/10.1016/j. archger.2013.03.013.

Larrieu, S., Pérès, K., Letenneur, L., Berr, C., Dartigues, J. F., Ritchie, K., et al. (2004). Relationship between body mass index and different domains of disability in older persons: the 3C study. International Journal of Obesity, 28, 1555-1560. http://dx.doi.org/10.1038/sj.ijo.0802755.

Lauretani, F., Semba, R. D., Dayhoff-Brannigan, M., Corsi, A. M., Di Iorio, A., Buiatti, E., et al. (2008). Low total plasma carotenoids are independent predictors of mortality among older persons: the InCHIANTI study. European Journal of Nutrition, 47(6), 335-340. http://dx.doi.org/10.1007/s00394-008-0732-9.

Lawton, M. P., \& Brody, E. (1969). Assessment of older people: self maintaining and instrumental activities of dailing living. The Gerontologist, 9, 179-186.

Lebrão, M. L., \& Duarte, Y. A. O. (2003). SABE-Saúde Bem-estar e Envelhecimento-O projeto SABE no município de São Paulo: uma abordagem inicial. Brasília: Organização Pan-Americana da Saúde.

Lee, Y., Kim, J., Back, J. H., Kim, S., \& Ryu, M. (2013). Changes in combined lifestyle risks and disability transition in older adults: korean Longitudinal Study of Aging, 2006-2008. Preventive Medicine, 56,124-129. http://dx.doi.org/10.1016/j. ypmed.2012.12.002.

Lima e Costa, M. F. F., Uchoa, E., Guerra, H. L., Firmo, J. O. A., Vidigal, P. G., \& Barreto, S. M. (2000). The Bambuí health and ageing study (BHAS): methodological approach and preliminary results of a population-based cohort study of the elderly in Brazil. Revista de Saúde Pública, 34(2), 126-135. http://dx.doi.org/ 10.1590/S0034-89102000000200005.

Lohman, T. G., Roche, A. F., \& Martorell, R. (1998). Anthropometric standardization reference manual. Champaign: Human Kinetics.

Maciel, A. C. C., \& Guerra, R. O. (2010). Influence of biopsychosocial factors on the survival of the elderly in northeast Brazil-a prospective study. Current Gerontology and Geriatrics Research. http://dx.doi.org/10.1155/2010/127605.

Marucci, M. F. N., Alves, R. P., \& Gomes, M. M. B. C. (2011). Nutrição em gerontologia. In S. M. C. S. Silva, \& J. D. P. Mura (Eds.), Tratado de alimentação, nutrição \& dietoterapia (pp. 461-488).São Paulo: Roca.

Massudi, H., Grant, R., Braidy, N., Guest, J., Farnsworth, B., \& Guillemin, G. J. (2012). Age-associated changes in oxidative stress and NAD+ metabolism in human tissue. PLoS One, 7(7), 1-9. http://dx.doi.org/10.1371/journal.pone.0042357.

Mecocci, P., Polidori, M. C., Troiano, L., Cherubini, A., Cecchetti, R., Pini, G., et al (2000). Plasma antioxidants and longevity: a study on healthy centenarians. Free Radical Biology \& Medicine, 28, 1243-1248. http://dx.doi.org/10.1016/ S0891-5849(00)00246-X.

Menezes, R. L., Bachion, M. M., Souza, J. T., \& Nakatani, A. Y. K. (2011). Estudo longitudinal dos aspectos multidimensionais da saúde de idosos institucionalizados. Revista Brasileira de Geriatria e Gerontologia, 14(3), 485-496.

Mezzetti, A., Lapenna, D., Romano, F., Costantini, F., Pierdomenico, S. D., De Cesare D., et al. (1996). Systemic oxidative stress and its relationship with age and illness. Journal of the American Geriatrics Society, 44(7), 823-827.

Michalakis, K., Goulis, D. G., Vazaiou, A., Mintziori, G., Polymeris, A., \& AbrahamianMichalakis, A. (2013). Obesity in the ageing man. Metabolism: Clinical and Experimental, 62, 1341-1349. http://dx.doi.org/10.1016/j.metabol.2013.05.019.

Moreira, P. L., \& Boas, P. J. F. V. (2011). Nutritional status and functional capacity of institucionalized elderly in Botucatu/SP. Geriatria E Gerontologia, 5(1), 19-23.

Moreira, P. L., Boas, P. J. F. V., \& Ferreira, A. L. A. (2014). Associação entre estresse oxidativo e estado nutricional de idosos. Journal of the Brazilian Medical Association, 60(1), 75-83. http://dx.doi.org/10.1590/1806-9282.60.01.016.

Moreira, P. L., Corrente, J. E., Boas, P. J. F. V., \& Ferreira, A. L. A. (2014). Dietary patterns are associated with general and central obesity in elderly living in a Brazilian city. Journal of the Brazilian Medical Association, 60(5), 457-464. http://dx.doi. org/10.1590/1806-9282.60.05.014.

Mutlu-Türkoğlu, U., Ilhan, E., Oztezcan, S., Kuru, A., Aykaç-Toker, G., \& Uysal, M. (2003). Age-related increases in plasma malondialdehyde and protein carbonyl levels and lymphocyte DNA damage in elderly subjects. Clinical Biochemistry, 36 (5), 397-400. http://dx.doi.org/10.1016/S0009-9120(03)00035-3.

Nam, S., Kuo, Y. F., Markides, K. S., \& Al Snih, S. (2012). Waist circumference (WC), body mass index (BMI), and disability among older adults in Latin American and the Caribbean (LAC). Archives of Gerontology and Geriatrics, 55, e40-e47. http:// dx.doi.org/10.1016/j.archger.2012.04.006.

Nascimento, C. M., Ribeiro, A. Q., Cotta, R. M. M., Acurcio, F. A., Peixoto, S. V., Priore, S. E., et al. (2012). Factors associated with functional ability in Brazilian elderly. Archives of Gerontology and Geriatrics, 54, 89-94. http://dx.doi.org/10.1016/j. archger.2011.08.005.

Nielsen, F., Mikkelsen, B. B., Nielsen, J. B., Andersen, H. R., \& Grandjean, P. (1997). Plasma malondialdehyde as biomarker for oxidative stress: reference interval and effects of life-style factors. Clinical Chemistry, 43, 1209-1214.
Organización Panamericana de la Salud (2003). Guía clínica para atención primaria a las personas mayores. Washington: OPAS.

Okamura, T., Hayakawa, T., Hozawa, A., Kadowaki, T., Murakami, Y., Kita, Y., et al. (2008). Lower levels of serum albumin and total cholesterol associated with decline in activities of daily living and excess mortality in a 12-year cohort study of elderly Japanese. Journal of the American Geriatrics Society, 56, 529-535. http://dx.doi.org/10.1111/j.1532-5415.2007.01549.x.

Ozbay, B., \& Dulger, H. (2002). Lipid peroxidation an antioxidant enzymes in Turkish population: relation to age, gender, exercise, and smoking. The Tohoku Journal of Experimental Medicine, 197(2), 119-124. http://dx.doi.org/10.1620/tjem.197.119.

Parahyba, M. I., \& Veras, R. (2008). Diferenciais sociodemográficos no declínio funcional em mobilidade física entre os idosos no Brasil. Ciência É Saúde Coletiva, 13(4), 1257-1264. http://dx.doi.org/10.1590/S141381232008000400022

Ramirez-Tortosa, M. C., García-Alonso, J., Vidal-Guevara, M. L., Quiles, J. L., Periago, M. J., Linde, J., et al. (2004). Oxidative stress status in an institutionalised elderly group after the intake of a phenolic-rich dessert. British Journal of Nutrition, 9 (6), 943-950. http://dx.doi.org/10.1079/bjn20041146.

Ramos, L. R., Simoes, E. J., \& Albert, M. S. (2001). Dependence in activities of daily living and cognitive impairment strongly predicted mortality in older urban residents in Brazil: a 2-year follow-up. Journal of the American Geriatrics Society, 49(9), 1168-1175.

Ramos, L. R. (2003). Fatores determinantes do envelhecimento saudável em idosos residentes em centro urbano: Projeto Epidoso, São Paulo. Cadernos de Saúde Pública, 19(3), 793-798. http://dx.doi.org/10.1590/S0102-311X2003000300011.

Ramsay, S. E., Whincup, P. H., Morris, R. W., Lennon, L. T., \& Wannamethee, S. G. (2008). Extent of social inequalities in disability in the elderly: results from a population-based study of british men. Annals of Epidemiology, 18(12), 896-903. http://dx.doi.org/10.1016/j.annepidem.2008.09.006.

Rizvi, S. I., \& Maurya, P. K. (2007). Markers of oxidative stress in erythrocytes during aging in humans. Annals of the New York Academy of Sciences, 1100, 373-382. http://dx.doi.org/10.1196/annals.1395.041.

Rodríguez López, S., Montero, P., Carmenate, M., \& Avendano, M. (2013). Functional decline over 2 years in older Spanish adults: evidence from the survey of health, ageing and retirement in Europe. Geriatrics \& Gerontology International, 14(2), 403-412. http://dx.doi.org/10.1111/ggi.12115.

Rodrigues, M. A. P., Facchini, L. A., Thume, E., \& Maia, F. (2009). Gender and incidence of functional disability in the elderly: a systematic review. Reports in Public Health, 25(Suppl. 3), S464-S476. http://dx.doi.org/10.1590/S0102$311 \times 2009001500011$

Sánchez-García, S., Sánchez-Arenas, R., García-Peña, C., Rosas-Carrasco, O., AvilaFunes, J. A., Ruiz-Arregui, L., et al. (2014). Frailty among community-dwelling elderly Mexican people: prevalence and association with sociodemographic characteristics, health state and the use of health services. Geriatrics $\mathcal{E}^{\circ}$ Gerontology International, 14(2), 395-402. http://dx.doi.org/10.1111/ggi.12114.

Saito, K., Yokoyama, T., Yoshida, H., Kim, H., Shimada, H., Yoshida, Y., et al. (2012). A significant relationship between plasma vitamin $\mathrm{C}$ concentration and physical performance among Japanese elderly women. The Journals of Gerontology. Series A, Biological Sciences and Medical Sciences, 67, 295-301. http://dx.doi.org/ $10.1093 /$ gerona/glr174.

Santos, C. A. S., Dantas, E. E., \& Moreira, M. H. (2011). Correlation of physical aptitude; functional capacity, corporal balance and quality of life (QoL) among elderly women submitted to a post-menopausal physical activities program. Archives of Gerontology and Geriatrics, 53, 344-349. http://dx.doi.org/10.1016/j. archger.2010.12.019.

Semba, R. D., Varadhan, R., Bartali, B., Ferrucci, L., Ricks, M. O., Blaum, C., et al. (2007). Low serum carotenoids and development of severe walking disability among older women living in the community: the Women's Health and Aging Study I. Age and Ageing, 36(1), 62-67. http://dx.doi.org/10.1093/ageing/afl122.

Stuck, A. E., Walthert, J. M., Nikolaus, T., Büla, C. J., Hohmann, C. \& Beck, J. C. (1999) Risk factors for functional status decline in community-living elderly people: a systematic literature review. Social Science \& Medicine, 48, 445-469. http://dx. doi.org/10.1016/S0277-9536(98)00370-0.

World Health Organization (1980). International classification of impairments, disabilities, and handicaps manual of classification relating to the consequences of disease. Geneva: WHO.

World Health Organization (1997). Obesity: preventing and managing the global epidemic: report of a WHO Consultation on Obesity. Geneva.

World Health Organization (2005). Envelhecimento ativo: uma política de saúde. Brasília: Organização Pan-Americana da Saúde.

Yeum, K. J., Lee-Kim, Y. C., Yoon, S., Lee, K. Y., Park, I. S., Lee, K. S., et al. (1995). Similar metabolites formed from beta-carotene by human gastric mucosal homogenates, lipoxygenase, or linoleic acid hydroperoxide. Archives of Biochemistry Biophysics, 321, 167-174. http://dx.doi.org/10.1006/abbi.1995.1382. 